Niniejsza publikacja jest dostępna na licencji Creative Commons. Uznanie autorstwa-Użycie niekomercyjne-Bez utworów zależnych 3.0 Polska. Pewne prawa zastrzeżone na rzecz autora. Zezwala się na wykorzystanie publikacji zgodnie z licencja - pod warunkiem zachowania niniejszej informacji licencyjnej oraz wskazania autora jako wtaściciela praw do tekstu. Treść licencji jest dostepna na stronie: http:// creativecommons.org/licenses/ by-nc-nd/3.0/ pl/

Lingwistyka Stosowana 16: 1/ 2016, 73-86

Monika J. NAWRACKA

\title{
Międzykulturowość w refleksyjnym nauczaniu języków obcych na przykładzie polskiego Perspektywa antropologiczna
}

\begin{abstract}
:
Interculturality in reflective teaching of foreign languages. Polish as an Example. An anthropolgical perspective

Through quality research and reflective approach we may observe the cultural dimensions of learning/ teaching of foreign languages. In my research on cultural aspect of learning/ teaching of Polish language as the next language I demonstrate the relation between the learner and the teacher in the endolingual environment and their perception of culture(s) as well as the impact on the effectiveness of the didactic processes. Using this perspective I describe the influence of decision making, opinions, stereotypes, choices, unconscious attitudes etc. on learning/ teaching and the possibility of taking these experiences into consideration in order to develop the teacher's reflective attitude, which results in a better and more effective teaching process.
\end{abstract}

\section{Wstęp}

Każdy z elementów tytułu poniższego artykułu pociąga za sobą szereg skojarzeń, definicji, odsyłając do ich ewolucji i historii zarówno w wymiarze osobistych doświadczeń uczących się oraz nauczających, jak i tych znanych z badań a także literatury. Dogłębne spojrzenie na ten temat, a co się z tym również wiąże wyłaniające się możliwości interpretacji, staje się szerokim zakreśleniem perspektywy w polifonicznej rzeczywistości, w której opisie często znajdujemy odniesienia do niejednoznacznych pojęć typu wielojęzyczność, wielokulturowość, różnojęzyczność etc.

Klamrę tekstu stanowi refleksyjność charakteryzująca i łącząca antropologię kultury oraz glottodydaktykę. W centrum obydwu tych dyscyplin znajduje się ukierunkowanie na osoby. Są nimi użytkownicy i użytkowniczki języków oraz kultur, uczący się ich oraz nauczający ${ }^{1}$, także badacze i badaczki.

\footnotetext{
${ }^{1} \mathrm{Za} \mathrm{W}$. Wilczyńską w tekście autorskim i w przywołaniach cytowanych prac, stosowane są określenia: „uczący się”/ „osoba ucząca się” i ,nauczający”/ „osoba nauczająca”. Taki wybór określeń to bezpośrednie wskazanie na podmiotowość partnerów i partnerek w relacji dydaktycznej. Badaczka proponując takie rozwiązanie, odwołuje się do stosowanych w literaturze dydaktycznej sformułowań: „learner” i „teacher” (ang.) oraz „apprenant” i „enseignant” (fr.) (W. Wilczyńska 1999: 29).
} 
W świetle powyższych uwag istotne jest wskazanie na (z)rozumienie roli kultury w nauczaniu i uczeniu się - w naszym przypadku języka polskiego jako obcego ${ }^{2}$. Szkicując tę propozycję interpretacji interesujących mnie zjawisk, odwołuję się do wybranej literatury przedmiotu. Źródłem refleksji ponadto stają się rozmowy - (wywiady) ${ }^{3}$ częściowo strukturyzowane ${ }^{4}-$ z osobami mającymi doświadczenie w uczeniu się/ nauczaniu JPJO.

\section{Refleksyjność}

Tytułowe międzykulturowość, refleksyjne nauczanie języków obcych oraz perspektywa antropologiczna odsyłają do interdyscyplinarnego ujęcia tematu. Warto przy tym odwołać się do słów Władysława Miodunki (2009a: 15), który odnosząc się do kultury w nauczaniu polskiego, pisał:

(...) znajdujemy się na polu badawczym o charakterze interdyscyplinarnym: na temat kompetencji kulturowej mogą się wypowiadać tacy specjaliści jak językoznawcy, literaturoznawcy, kulturoznawcy, czy też socjologowie kultury, etnologowie, antropologowie.

Wobec powyższego, antropologiczne spojrzenie na kulturę w uczeniu się/ nauczaniu, przejawiające się w definiowaniu przedmiotu badań i metodzie badawczej podporządkowane jest glottodydaktyce, która, jak podkreślają Anna Michońska-Stadnik i Weronika Wilczyńska (2010: 69-70), ujmuje rozwój kompetencji komunikacyjnej z perspektywy zależności między nauczaniem a uczeniem się.

Pojęcie refleksyjności używane jest na określenie świadomości procesu badawczego i konsekwencji obecności badaczy i badaczek. W badaniach antropologicznych refleksyjność przedstawiana jest jako najistotniejsza praktyka metodologiczna. Badacza/ badaczkę uznaje się za jedno z „narzędzi” - tzn. za element zmienny i uwarunkowany wieloma przesłankami np. światopoglądowymi, zapleczem intelektualnym, wykształceniem etc. (M. Banks 2013: 92-94). Celem jest nie tylko obserwowanie i eliminowanie ukrytych założeń, lecz także wykorzystywanie rozważań na temat przedstawień etnograficznych - tzn. że piszący etnograf/ pisząca etnografka, ale i każdy inny badacz/ badaczka są twórcami/ twórczyniami, tworzącymi „nieprzezroczyste” teksty i opisy.

Poprzez etnograficzne badania jakościowe dąży się do „przyjrzenia się światu zewnętrznemu” a zarazem wyjaśnienia go z perspektywy „wewnętrznej”. Celem przeprowadzanych analiz jest zaś opis - przy użyciu kategorii znaczących i bogatych w szczegóły - tego, w jaki sposób ludzie tworzą świat wokół siebie, co robią lub co im się przydarza. Uchwycenie doświadczeń, interakcji w ich naturalnym kontekście oraz powstrzymywanie się na wstępie badań od hipotez i dokładnego definiowania przedmiotu badawczego stanowi podstawę badań etnograficznych. (U. Flick 2011: 12-14).

$\mathrm{Na}$ gruncie glottodydaktycznym swoje teoretyczne refleksje badaniom jakościowym poświęciły m. in. A. Michońska-Stadnik i W. Wilczyńska (2010). Warto przy tym

${ }^{2}$ Dalej w tekście posługuję się skrótem JPJO.

${ }^{3}$ Ze względu na ograniczenia artykułu zrezygnowałam z cytowania wywiadów, pragnąc przez to uniknąć wybiórczego ich traktowania.

${ }^{4}$ Więcej o badaniach jakościowych w glottodydaktyce np. A. Michońska-Stadnik/ W. Wilczyńska (2010), w naukach społecznych i humanistycznych P. Atkinson/ M. Hammersley 2010, M. Banks 2013, B. Gibbs 2011, U. Flick 2011. 
wziąć pod uwagę, że wg tych autorek badania jakościowe stosowane w glottodydaktyce dobrze oddają indywidualne postawy oraz wyobrażenia. Należy przy tym uwzględnić wpływ kontekstu, charakter indywidualnych procesów czy zjawisk leżących w centrum zainteresowań tej dyscypliny. Dzięki nim można uchwycić opisywane fenomeny zwłaszcza te nowe czy słabiej rozpoznane - w pełniejszym zrozumieniu ich dynamiki oraz uwarunkowań. Ogromną zaletą opisywanej metody staje się możliwość uchwycenia różnorodności z perspektywy badanych (tamże: 139-145).

Celem refleksyjnych badań jakościowych oraz wyrabiania refleksyjnej postawy nauczających jest uświadamianie różnych wymiarów doświadczeń - $\mathrm{m}$. in.: wiedzy ukrytej, przekonań, wartości, uwarunkowań, sposobów podejmowania decyzji, które mogą wpływać na procesy nauczania i uczenia się. Kultura bowiem to proces negocjacji pomiędzy nauczającymi oraz uczącymi się, kontekstem, jawnymi i ukrytymi treściami nauczania etc ${ }^{5}$. Dzięki postawie refleksyjnej a także badaniom jakościowym zdobywamy dostęp do doświadczeń z pierwszej ręki - teorii osobistych, zwanych również subiektywnymi teoriami uczących się/ nauczających dotyczących języka, uczenia się oraz komunikacji (A. Michońska-Stadnik/ W. Wilczyńska 2010: 55).

Poprzez wydanie książki pt. Jak uczyć lepiej? czyli refleksyjny praktyk w działaniu i korzystając z podejścia Donalda Schöna, Małgorzata Taraszkiewicz przyczyniła się do popularyzacji podejścia refleksyjnego. Według niej refleksyjny praktyk:

(...) to osoba, która myśli o tym, co aktualnie robi. Poddaje refleksji swoje funkcjonowanie, a zatem strukturę swoich przekonań, które określają własny sposób myślenia i działania. Pracuje poprzez autorefleksję i otrzymywane informacje zwrotne. Studiuje i bada swój warsztat pracy, założenia i rezultaty; analizuje doświadczenia, wprowadza zmiany. (M. Taraszkiewicz 1998: 19).

Dla M. Taraszkiewicz refleksyjny praktyk to osoba aktywna - ucząca się, odnosząca się do nowości oraz kreatywnie z nich korzystająca. W jej propozycji wiedza naukowa stanowi ważny ,punkt oparcia” inspirujący do tworzenia własnego warsztatu.

Powstaje pytanie: czy wobec określonych kulturowo, osobowościowo mniej lub bardziej uświadomionych strategii uczenia się należy/ można je podtrzymywać czy wprowadzać nowe i inne. $\mathrm{W}$ odpowiedzi na powyżej zarysowane pytanie należy moim zdaniem wziąć za W. Wilczyńską (1999: 208-210),„świadomość własnej specyfiki uczeniowej”, uwzględniając ogólne kierunki działania w refleksyjnym nauczaniu zorientowanym na uczącego się. Poznawanie ,specyfiki uczeniowej” obejmuje poznawanie generalnych uwarunkowań i czynników uczenia się w celu właściwego formułowania sądów o uczących się, tolerancję wobec ich wyborów będących efektem świadomych i wyważonych decyzji, uznawanie różnic indywidualnych, ale nie z zamiarem dostosowania się do nich. Takie założenie byłoby zdaniem W. Wilczyńskiej zamiarem utopijnym i jałowym. Sugeruje ona raczej otwarty styl nauczania stymulujący indywidualny rozwój np. poprzez stwarzanie okazji do zastosowania różnych strategii z naciskiem na wypróbowywanie tych dotąd niepraktykowanych.

Pamiętając, że refleksyjni nauczający mogą stawać się wzorem dla uczących się, inspirując i wspomagając postawę refleksyjną a także autonomiczne działania uczących się (por. W. Wilczyńska 1999: 209, M. Piotrowska-Skrzypek 2008: 248), wydaje się,

${ }^{5}$ Por. M.J. Kirkebæk/ X.Y. Du/ A.A. Jensen 2013.

Lingwistyka Stosowana/ Applied Linguistics/ Angewandte Linguistik: www.ls.uw.edu.pl 
że odpowiedzią na powyższe pytanie może stać się wypracowywanie rozwiązań na pograniczu kultur. Zakładając, że uczenie się może być się konfrontacją z czymś nowym, po części charakteryzującym kulturę docelową, uważam że przedstawione powyżej podejście zgodne jest z postrzeganiem nauczania jako doświadczenia transformacyjnego.

\section{Międzykulturowość}

Powyższe pojęcie implikuje istnienie $\operatorname{kultur}(y)$. Kultura wymyka się jednoznacznym a zarazem wyczerpującym opisom/ definicjom i jako pojęcie stosowane jest w obrębie wielu dziedzin badawczych. Choć z pozoru jest raczej terenem zastrzeżonym dla innych dyscyplin i badaczy/ badaczek je reprezentujących, np. antropologów i antropolożek kultury, przyjmuje się, że kultura „od zawsze” jest obecna w nauczaniu/ uczeniu się języków, ale raczej jako podporządkowany/niedostrzegany element/ wymiar nauczania/ uczenia się języków. ${ }^{6}$

Niezależnie do tego, czy nauczany język to język obcy, drugi czy (o)dziedziczony, kultura ze współczesnej perspektywy - tzn. z połowy drugiej dekady XXI wieku - wydaje się nieodłącznym i wręcz kluczowym elementem procesu uczenia się/ nauczania, pomocnym w zrozumieniu zachowań społecznych i indywidualnych, światopoglądu itd. W bogatej literaturze znajdujemy różne - czasem dość enigmatyczne - koncepcje relacji „kultura” a ,język”, roli kultury w uczeniu się/ nauczaniu języków. Formułuje się opinie, że język jest częścią kultury, a kultura jest częścią języka, albo kultura jest językiem, a język kulturą, że są nierozerwalne, kultura w nauczaniu języków jest „,inguakulturą" bądź „languakulturą”, albo mamy do czynienia z „kulturą-i-językiem” lub „kulturojęzykiem". ${ }^{7} \mathrm{~W}$ literaturze przedmiotu dostępnej po polsku, także odnoszącej się do nauczania JPJO, napotykamy m.in. następujące określenia: „,komponent kulturowy”, „treść kulturoznawcza”, ,treści kulturowe”, „,wiedza o kulturze”, „treści kulturopoznawcze”, ,elementy kultury”, „lingwakultura”, „przestrzeń kulturowa” oraz „realia”. Pojawiają się różne próby opisu zjawisk czy sposobu ich przedstawiania: „paradygmat kulturowy”, „fenomen kulturowy”, „dekalog kulturowy”, ,algorytm zachowania kulturowego”, „kulturowe inwentarze/ obrazki” etc.

Wobec mnogości terminów i ujęć trwają poszukiwania odpowiedniego terminu na określanie kultury w nauczaniu JPJO - jako po prostu kultury (culture w nauczaniu angielskiego), cywilizacji czy kultury (civilisation/ culture, civilta/ cultura w nauczaniu języków romańskich), realioznawstwa (Landeskunde na gruncie języka niemieckiego). W pracach polskich glottodydaktyków i glottodydaktyczek, także w zakresie glottodydaktyki polonistycznej również nie widać ujednolicenia terminów. Nabiera to szczególnie znaczenia, kiedy weźmie się pod uwagę standaryzację i europeizację (w odniesieniu do standardów Rady Europy) kształcenia językowego w Polsce (P.E. Gębal 2013: 78$79,98)$.

Widoczna jest potrzeba zwiększenia świadomości, czym jest kultura, czym jest kultura w uczeniu się/ nauczaniu języków (np. prace A. Burzyńskiej, P. Garncarka, P.E Gębala, W. Miodunki, G. Zarzyckiej). Świadectwem tego są toczące się dyskusje.

\footnotetext{
${ }^{6}$ Por. np. Prace P.E. Gębala 2009, 2010.

${ }^{7}$ Przytoczenia za A. Heidari, S. Ketabi, R. Zonoobi 2014.
} 
Nawet nie werbalizując tego, autorzy i autorki np. przewodników metodycznych biorą udział w dyskusjach o kulturze; sugerując treści zajęć, dzieląc się pomysłami na jej odkrywanie i nauczanie ${ }^{8}$. Mimo to wydaje się, że w glottodydaktyce polonistycznej studia nad kulturą wciąż stanowią temat, do którego można wprowadzać nowe perspektywy i weryfikować dotychczasowe podejścia oraz teorie, szczególnie w konfrontacji z badaniami dotyczącymi innych języków. Zwłaszcza że w zakresie pragmatyki języka polskiego, zasad kulturowych czy wartości polszczyzna wciąż pozostaje mało opisana9 ${ }^{9}$.

Podejmowaniu badań nad kulturą w uczeniu się/ nauczaniu towarzyszą pytania: po co je prowadzić i czym jest kultura w nauczaniu. Badania prowadzą do rozumienia i uświadamiania kultury docelowej, ale własnej i innych kultur (na ten temat P.E. Gębal 2010), szczególnie w zakresie postrzegania tego, czym jest nauczanie/ uczenie się, jakie role odgrywają uczący się/ nauczający etc. Wraz z zachodzącymi procesami internacjonalizacji, globalizacji, studiami postkolonialnymi, rosnącą mobilnością, kultury i języki nie są utożsamiane wyłącznie z narodami oraz narodowymi identyfikacjami ${ }^{10}$. Przy ich analizie wskazane wydaje się uwzględnianie międzynarodowych procesów, sieci i wspólnot, także zmienności historycznej oraz wariantywności wynikającej z subiektywności. Zdaniem niektórych kultura polska a także język polski są wyjątkowe i wymagają specjalnych narzędzi, ponieważ prezentują inną tzn. własną perspektywę motywowaną historycznie, nieobejmującą np. refleksji postkolonialnej. Mimo to wydaje się, że warto mieć na uwadze fakt, że polskiego oraz kultury polskiej uczą się osoby z kultur dyskutujących i uczestniczących we współczesnych przewartościowaniach. Zresztą owe przewartościowania znajdują swoje odbicie np. jako nowe spojrzenie na historię czy przejawiają się w konfliktach modelowych ról osób nauczających i uczących się wynikających $m$. in. z reprezentowania odmiennych systemów kulturowych, które na swój sposób definiują role uczących się i nauczających ${ }^{11}$.

Podejście do nauki języków obcych oraz badania na ten temat rozwijają się z odniesieniami do studiów kulturowych, antropologii, socjologii, pragmatyki etc. Jednocześnie zmienia się myślenie o kulturze i następuje przejście od tradycyjnego/ klasycznego modelu reprezentującego spuściznę narodową, utożsamianego ze sztuką i literaturą, do perspektywy uwzględniającej różne sposoby życia danej wspólnoty językowej w obrębie granic narodowych lub ponad nimi. Tak przedstawiony rozwój zarówno spojrzenia na kulturę i dydaktykę języków sprawia, że celem nie jest dążenie do biegłości rodzimego użytkownika/ rodzimej użytkowniczki języka/ kultury ${ }^{12}$. Współczesny stosunek do języków i kultur zakłada mniej normatywne podejście, bardziej komunikacyjne, otwarte na wariantywność oraz językowe i kulturowe spotkania. Celem uczenia się języków obcych jest nie tylko nabycie umiejętności porozumiewania się z osobami odmiennymi kulturowo, o różnych identyfikacjach i zapleczu kulturowym, lecz także nabywanie kompetencji międzykulturowej. (H. L. Andersen/ K. Lund, K. Risager 2006: 7-8).

W dydaktyce JPJO obserwujemy 3 podejścia do nauczania kultury: faktograficzne,

\footnotetext{
${ }^{8}$ Zob. A. Dąbrowska/ U. Dobesz/ M. Pasieka 2010.

${ }^{9}$ Por. z pracą na temat pragmatyki językowej L. Ruiz de Zarobe/ Y. Ruiz de Zarobe 2012: 11.

${ }^{10}$ Więcej na ten temat C. Kramsch 2006 i H. L. Andersen/ K. Lund/ K. Risager 2006.

${ }^{11}$ Por. Piekot, T./ G. Zarzeczny 2010.

${ }^{12}$ Co komplikuje się jeszcze bardziej, gdy spróbujemy zdefiniować „,modelowego użytkownika/ modelową użytkowniczkę języka obcego".
} 
komunikacyjne i międzykulturowe (P.E. Gębal 2010). Cenne wydaje się choćby pobieżne spojrzenie na analizy poświęcone kulturze w nauczaniu języków tzw. światowych, by wyrobić sobie zdanie o ścieżkach refleksji dydaktycznych. Jest to istotne zwłaszcza w próbach przenoszenia i/ lub adaptowania rozwiązań z gruntu innych języków.

Wg C. Kramsch od wieku XIX kultura jako domena klasy średniej była promowana przez system szkolnictwa, zaś narracje narodowe uznawały język za narzędzie homogenicznych wspólnot narodowych. Do II wojny światowej kulturę utożsamiano z literackim bądź humanistycznym elementem nauczania języków. Po wojnie i po „przewrocie” komunikacyjnym postrzegano ją jako sposób życia, zachowań członków i członkiń wspólnot językowych, połączonych wspólnymi doświadczeniami. Obecnie - kiedy kultury narodowe, kolektywne wydają się w odwrocie, tworzą hybrydy, nie są ograniczone terytorialnie - takie ujmowanie kultury stało się problematyczne. Zatem jakiej kultury należy nauczać? Narodowej, regionalnej, globalnej? To pytanie implikuje następne: która z dziedzin nauki powinna się tym zająć? ${ }^{13}$ (C. Kramsch 2006: 15-17)

C. Kramsch z jednej strony wyróżnia perspektywę modernistyczną, ukazującą homogeniczną i terytorialną kulturę - uwzględniającą podejścia humanistyczne (zainteresowanie literaturą i sztuką), socjolingwistyczne (akcent na życie codzienne, normy, konwencje). $Z$ drugiej zaś strony dostrzega podejście międzykulturowe oraz perspektywę postmodernistyczną - traktującą kulturę jako subiektywną, zróżnicowaną, mobilną i połączoną z indywidualną uwarunkowaną kontekstowo historią. W tej ostatniej postawie, czerpiąc z interdyscyplinarności, traktuje się uczących się języków - obcych, drugich i (o)dziedziczonych - podmiotowo.

W latach 80. wraz z podejściem komunikacyjnym zaczęto stosować bardziej pragmatyczne spojrzenie na kulturę. Postrzegano ją jako sposób życia, komunikacji, interakcje, zasady kształtujące życie na co dzień (zachowania, sposoby jedzenia, prowadzenia rozmów, wierzenia, wartości). Koncentrowano się m.in. na pragmatyce, nauczając zasad socjolingwistycznych tak, jak nauczano gramatyki. Jednak wciąż kultura była postrzegana jako monolit, tak jak i rodzimi użytkownicy i użytkowniczki języków, co w praktyce oznaczało koncentrację na typowych, nierzadko stereotypowych czy „egzotycznych" zachowaniach (C. Kramsch 2006: 11-14).

Z perspektywy postmodernistycznej kultura łącząca nierozerwalnie język oraz myśl to domena badań nad komunikacją i edukacją, zaś międzykulturowość uwzględnia kontakt między osobami o różnorodnym zapleczu kulturowym. Wskazuje się, że każda wypowiedź znajduje się w asymetrycznych relacjach władzy, w których negocjuje się znaczenia. Nastąpiło przesunięcie akcentu z kultury na dynamiczne, wielokrotne i sprzeczne identyfikacje - także grupowe i indywidualne (C. Kramsch 2006: 17).

Interesujące nas podejście międzykulturowe (międzykulturowość) wyłoniło się w latach 80. XX w. na gruncie komunikacji i edukacji. Jego celem było/ jest zwiększenie dialogu, współpracy pomiędzy członkami i członkiniami różnych wspólnot, kultur narodowych. Postrzegane jest jako element edukacji humanistycznej, szczególnie mocno propagowany w Skandynawii czy Niemczech (C. Kramsch 2006: 14).

\footnotetext{
${ }^{13}$ Należy podkreślić, że w przywoływanym tekście autorka analizuje kulturę m.in. w nauczaniu języka angielskiego w USA i Europie a także jego wpływ mniej lub bardziej bezpośredni na inne dydaktyki.
} 
Pojawiło się ono wraz z koncepcją „kompetencji komunikacyjnej”. Jest mniej skoncentrowane na osiągnięciu językowej oraz pragmatycznej biegłości a bardziej na subiektywnym doświadczeniu osoby uczacej się zaangażowanej w proces stawania się bilingwalna badź wielojęzyczna i borykania się [struggling] z innym językiem, inna kultura $i$ identyfikacja (C. Kramsch 2006: 14-15) oraz analizie siebie i innych. Dzięki kompetencji międzykulturowej w nauczaniu/ uczeniu się języków następuje rozwój i wzbogacenie całej osobowości i tożsamości poprzez doświadczanie inności (the otherness) poprzez język i kulturę (M. Byram 2010: 319; Europejski system opisu ksztatcenia językowego: uczenie się, nauczanie, ocenianie, ${ }^{14}{ }^{15}$ 2003: 50-51, W.T. Miodunka 2009b: 100).

$\mathrm{Z}$ perspektywy europejskiej podejście międzykulturowe jest kojarzone $\mathrm{z}$ jednoczeniem się Europy. Eksponuje się w nim uzyskiwanie kompetencji międzykulturowej, rozumianej jako umiejętność porozumiewania się z osobami o różnym zapleczu kulturowym. Podejście to jest konsekwencją uznania nierozłączności języka i kultury, stanowiąc wypadkową umiejętności językowych, kulturowych, komunikacyjnych, psychologicznych a z punktu widzenia nauczających pedagogicznych oraz umiejętności uczenia się. Kompetencja międzykulturowa ułatwia lepsze zrozumienie nie tylko kultury obcej, ale $i$ własnej, gdyż ta druga również jest obecna na każdych zajęciach z języka obcego (P.E Gębal 2009: 73) ${ }^{16}$. Wyjściowy język i kultura (język i kultury) stanowią zawsze odniesienie dla uczących się i nauczających.

Analizując refleksję międzynarodową i polską, warto odwołać się do Przemysława E. Gębala. W swych pracach (m. in. 2010, 2013) formułuje i proponuje zasady glottodydaktyki porównawczej, realizując postulat W. Miodunki, by w glottodydaktyce polonistycznej refleksyjnie korzystać z dokonań innych dydaktyk, m. in. języków światowych. (P.E Gębal 2013: 85-87). ${ }^{17}$

P.E Gębal podsumowując współczesny stań badań i refleksji również nad miejscem kultury w nauczaniu języków, wpisuje glottodydaktykę polską w kontekst europejski. Oznacza to m.in. prawne aspekty funkcjonowania Polski w ramach Unii Europejskiej, z drugiej zaś strony istnienie zasad, w ramach których polskie systemy kształcenia i ich realizatorzy oraz realizatorki muszą się odnaleźć. Jak wskazuje ten autor, wielojęzyczność (różnojęzyczność) i wielokulturowość są pojęciami, które w największym stopniu kształtują rozwój glottodydaktyk (P.E. Gębal 2013: 40-43). Postawa międzykulturowa ${ }^{18}$ jawi się zarazem jako produkt jak i cel współczesnego nam nauczania języków. Mobilność, kontakty i możliwości komunikacyjne wymagają nowych bądź wzmacnianych kompetencji.

Kompetencja międzykulturowa bywa opisywana jako przyjęcie czy raczej uwzględnienie perspektywy innej osoby, nietraktowanie siebie i własnego punktu widzenia jako najważniejszych i dominujących. Oznacza to także akceptację oraz „dopuszczanie do głosu" innej osoby, osoby z innej kultury. To również przewidywanie i reagowanie na

\footnotetext{
${ }^{14} \mathrm{~W}$ dalszej części tekstu korzystam ze skrótu ESOKJ.

${ }^{15} \mathrm{Nie}$ odnoszę do nieobecnego właściwie w polskich analizach czy propozycjach programowych A Framework of References of Pluralistic Approaches (franc. Un Cadre de Référence pour Les Approaches Plurielles).

${ }^{16}$ Por. P.E. Gębal 2013: 41-42.

${ }^{17}$ Więcej na ten temat P.E Gębal 2014.

${ }^{18}$ Promowana przez swą prekursorkę na gruncie polskim G. Zarzycką.
} 
możliwe zaburzenia komunikacji, (nie)adekwatność zachowań np.: prośby, wyrażanie zgody i niezgody, możliwość odmiennego od założonego postrzegania. Model Michaela Byrama (1997) zakłada umiejętność interpretacji, samodzielnego odkrywania, podejmowania interakcji, obejmując również krytyczną świadomość kulturową. Wiedza obejmuje poznanie grup społecznych, produktów, procesów i interakcji, zaś postawę międzykulturową charakteryzuje ciekawość i otwartość wobec innych, a także gotowość do zmiany wartości kulturowych oraz przekonań, podjęcia współpracy i zaangażowania się. Ponadto próby rozumienia perspektyw kulturowych, pośredniczenia między nimi w nowych kontekstach, nabywania wiedzy, wypracowywania postaw i umiejętności, a także świadomość krytyczna jest definiowana jako zdolność do krytycznej oceny perspektyw i praktyk we własnej kulturze oraz innych kulturach (A. Heidari/ S. Ketabi/ R. Zonoobi 2014).

Także w ESOKJ akcentuje się kompetencję socjolingwistyczną i rolę działań mediacyjnych - w tym rolę pośrednika kulturowego. Autorzy dokumentu zwracają uwagę na osobowościowe i kulturowe uwarunkowania komunikacji, postrzegając kulturę jako „drażliwy punkt” w kontaktach międzykulturowych. Z drugiej strony wrażliwość interkulturowa jest dla autorów jedną z kluczowych umiejętności, prowadzącą do skutecznej komunikacji. Skuteczna komunikacja oznacza dla nich wypadkową uwzględniania i przezwyciężania stereotypów, zróżnicowania społecznego i kulturowego, znajomości języków oraz kultur. Celem nauczania staje się, by świadomi uczestnicy i uczestniczki komunikacji (w tym uczący się języków) zdobywali umiejętność postrzegania związków między kulturami (własną i obcą), wrażliwość, umiejętność wybierania strategii i sposobów wyrażani siebie.

Nie do przecenienia $\mathrm{w}$ tym dokumencie pozostaje element związany ze zmianami tożsamościowymi ${ }^{19}$. W ESOKJ (2003: 23-24, 96-97, 117-118, 128-129, 133-134 i nast.) z jednej strony podkreślona została wspólnota kultury europejskiej, z drugiej zaś zróżnicowanie kulturowe między państwami, narodami, regionami, klasami lub grupami społecznymi a także płciami. W takim ujęciu autorzy wskazują istotne ryzyko związane z próbami przedstawienia użytkownikom i użytkowniczkom języków oraz kultur - ryzyko wymuszone przez uogólnienia, odwoływanie się do stereotypów czy korzystanie z technik informacyjnych i podawczych.

Kwestie kulturowe w ESOKJ są rozproszone. Znajdują się one m. in. w części poświęconej uwarunkowaniom osobowościowym, postawom, relatywizacji opinii oraz punktów widzenia czy systemów wartości, a także dystansowaniu się wobec konwencjonalnych nastawień do różnic kulturowych. Takie rozproszenie moim zdaniem oddaje stan myślenia o kulturze nauczających (nauczycieli i nauczycielek, osób odpowiedzialnych za programy oraz autorstwo materiałów). Wydaje się to zrozumiałe, ponieważ kultura nie poddaje się łatwym opisom i jest zjawiskiem złożonym, czego świadectwem zdają się toczone dyskusje.

\footnotetext{
${ }^{19}$ Można mieć wątpliwości co do poniektórych stwierdzeń w dokumencie, czy są one uprawnione i uzasadnione np. ,wrodzone umiejętności socjolingwistyczne” i ,pragmatyczne”. Owe umiejętności są przyswajane wraz z socjalizacją i enkulturacją, które, jak same nazwa wskazuje, są procesami ściśle powiązanymi z kulturą i wychowaniem. Takie próby nakreślenia zjawisk motywowanych językowo i kulturowo wskazują na trudności mówienia o kulturze i szukania odpowiedniego języka opisu. Konfrontując je z deklaracjami autorów, przyjmuję, że celem jest wyrabienie umiejętności korzystania z potencjału uczących się.
} 
W polskiej literaturze realizacją założeń kompetencji międzykulturowej jest propozycja Marty Torenc (2007), w której kładzie ona nacisk na proaktywną postawę uczących się, ich otwarcie na odmienność, ale i zrozumienie własnego zaplecza językowokulturowego ${ }^{20}$. Natomiast P. Gębal, odnosząc refleksję na temat międzykulturowości do JPJO, w swoich pracach zwraca uwagę na kontakt z kulturą i osobiste, subiektywne jej doświadczanie - bezpośrednio w Polsce bądź zagranicą:

(...) Nauczanie języka polskiego jako obcego i przekazywanie treści realioznawczych w Polsce odbywa się w inny sposób niż jego nauczanie w sąsiadujących krajach słowiańskich, pozostałych krajach europejskich i w reszcie świata. Uczący się języka w Polsce stykają się z obcą dla nich kulturą na co dzień. Im dalej od Polski, tym mniejsza możliwość bezpośrednich kontaktów. „Przeżywanie” obcej kultury może odbywać się tam tylko podczas wykonywania rożnego rodzaju zadań i lektury tekstów (P.E Gębal 2010: 185, por. 36-38).

Ważna przy tym wydaje się refleksja Anny Jaroszewskiej, wg której wzbogacenie kultur, osób je reprezentujących, czerpie z postaw prospołecznych wyrażanych $\mathrm{m}$. in. w zainteresowaniu innością kulturową, potrzebą poznania i uczestniczenia w niej. W tym zakresie wszystko zależy od kompetencji indywidualnych, z których powstają zmiany relacji między przedstawicielami oraz przedstawicielkami różnych kultur:

(...) Wzmożone procesy interakcji zachodzące między nimi są wyrazem transpozycji kulturowych relacji z wielokulturowości (reakcyjności) na międzykulturowość (interakcyjność). Przeobrażenia takie nie byłyby możliwe, gdyby nie potrzeby poznawcze i postawy życiowej aktywności, tolerancji, zrozumienia i akceptacji dla „inności” (...) (A. Jaroszewska 2013: 100).

Kompetencja międzykulturowa jest zmienna w czasie - uczący się jak i nauczający dysponują nią oraz rozwijają ją w kontaktach międzykulturowych. Ważne przy tym jest, czy odbywa się to w kontakcie z osobami z kultury docelowej, w kraju kultury docelowej, czy wyłącznie w ramach zajęć językowych. Niemniej ważna jest postawa uczących się (i nauczających): czy ich zainteresowania skłaniają do samodzielnych poszukiwań i autonomicznych działań zmierzających do rozwoju kompetencji językowej oraz międzykulturowej.

\section{Perspektywa antropologiczna}

Dysponujemy programami, listami zagadnień, katalogami zagadnień, analizami, czy postulatami tworzenia klarownych, zamkniętych opisów uczących się, kultur docelowych, czy propozycji przedstawiania ich odbiorcom oraz odbiorczyniom. Są to jednak w większości moim zdaniem podejścia niedynamiczne, nie dość elastyczne i często trudne do przełożenia na praktykę uczenia się/ nauczania, ponieważ nie uwzględniają indywidualnych biografii językowo-kulturowych.

Warto przy tym brać pod uwagę, że współczesność oraz koncentracja na uczących się wymagają zweryfikowania poglądów, zarówno na nauczanie jak i na procesy zachodzące w uczeniu się. Wielojęzyczność i wielokulturowość w panującym paradygmacie międzykulturowości otwierają przestrzeń dla nowych narzędzi opisu. ${ }^{21}$ Biorąc pod uwagę spojrzenie na zajęcia z języków obcych jako na spotkanie minimum dwóch kultur

${ }^{20}$ Por. prace P. Gębala, A. Jaroszewskiej, G. Zarzyckiej.

${ }^{21}$ Por. W. Wilczyńska 2007: 39. 
i języków ${ }^{22}$, mamy możliwość prowadzenia wzbogacającej refleksji, która może stawać źródłem rozwoju i to dwóch stron interakcji - uczących się i nauczających.

Użytecznym narzędziem w prowadzeniu zajęć językowych w modelu wspierania rozwoju kompetencji międzykulturowej może być antropologia kultury. Poniżej odwołuję się do klasycznego już tekstu Beverly McLeod (1976), w którym w bardzo uniwersalny a przez to aktualny sposób opisuje pożytki korzystania z podejścia antropologicznego w nauczaniu języka angielskiego w USA. Wiele z jej uwag, moim zdaniem, może być przydatnych w nauczaniu dowolnego języka.

Zdaniem B. McLeod, zajęcia wolne od wartościowania czy ocen, na których otwarcie dyskutuje się, mogą posłużyć za pomoc w wytworzeniu neutralnej czy wręcz przyjaznej atmosfery ${ }^{23}$, w której zarówno uczący się jak i nauczający mogą stać się adeptami i adeptkami antropologii, dzięki której odkrywają swoje kultury. Ponieważ zajęcia językowe to także nauczanie kultury, rozwój umiejętności komunikacyjnych; od nauczających oczekuje się wiedzy o zapleczu językowo-kulturowym uczących się ${ }^{24}$. Co wobec tego może zaoferować antropologia? Jakimi dysponuje narzędziami? Żeby odpowiedzieć na to pytanie, należy wziąć pod uwagę kulturę - rozumianą jako m.in. system wartości danego społeczeństwa, którego reguły mogą być zaobserwowane przez outsiderów - osoby spoza niego. Ukazywanie równości kultur jako spójnych systemów realizujących potrzeby swoich członków oraz członkiń a także porównywanie kultur może przyczynić się do scharakteryzowania każdej z nich. (B. McLeod 1976: 211-212).

Zakładając, że kulturę przyswajamy ${ }^{25}$ jak język - to znaczy przez ekspozycję od dzieciństwa - uznaję, że kultura jest wyuczonym (przyswojonym) zachowaniem, które jest realizacją kulturowych wartości, wierzeń, sposobów postrzegania etc. Zatem można nauczyć się kultury tak, jak można nauczyć się języka. Dalej McLeod argumentuje, że dorośli tak samo jak w przypadku nauki języka, potrzebują wsparcia w poznawaniu kultury. Jej zdaniem powinna być ona nauczana eksplicytnie, ponieważ dysponują oni zbyt ograniczonym czasem na naukę implicytną, by przechodzić proces stawiania hipotez i testowania. Ponadto bardzo wiele aspektów kultury jest nabywanych w czasie dzieciństwa i dorastania, więc jest to bezsprzecznie etap niemożliwy do odtworzenia dla dorosłych. Co więcej, implicytność nabywania kultury przez dorosłych jest zagrożona niezrozumieniem przekazu, błędnymi interpretacjami do czasu uczynienia ich eksplicytnymi. Ważne przy tym jest, by nauczający mieli świadomość ukrytych wartości, informacji nauczanej kultury i współtworzyli okazję do mówienia o nich oraz ich analizy.

\footnotetext{
${ }^{22} \mathrm{~Np}$. nauczający i uczący się z dwóch kultur narodowych, gdy język docelowy jest językiem ojczystym nauczającego (Brytyjka ucząca angielskiego Polaków), nauczający i uczący się z jednej kultury narodowej (polski nauczający i polscy uczący się na zajęciach z francuskiego), nauczający i uczący się dwóch kultur narodowych uczący się języka niebędącym pierwszym dla żadnej z osób (Czeszka ucząca polskiego Portugalczyków i Portugalki bądź niemieckiego Polaków) etc.

${ }^{23}$ Autorka mówi o relatywizmie kulturowym jako postawie, która ma pomóc w kreowaniu takiej atmosfery/ przestrzeni.

${ }^{24}$ Por. W.T. Miodunka (2009b: 105): „(...) W istocie uczący się języka polskiego oczekują od nas kontrastywnego opisu kultury polskiej, uwzględniającego porównanie z elementami ich własnej kultury".

${ }^{25}$ W oryginale ,learn”.
} 
Taką świadomość można nabyć dzięki własnym studiom, lekturom i dzięki znajomości innych kultur. Kluczowym wydaje się rozumienie przekazywanych wartości i wartości z kultur osób uczących się (B. McLeod 1976: 212).

W nauczaniu grup homogenicznych pomocą okazują się informacje, programy szkoleniowe zaznajamiające ze specyfiką pracy danej grupy o określonym zapleczu kulturowym. Jednak w pracy z grupami heterogenicznymi, oczekiwanie znajomości każdej z kultur, z których pochodzą uczący się, jest nierealne. Nierzadko nauczający napotykają wyzwanie w postaci nauczania osób z nieznanej kultury. W takiej sytuacji przydatna wydaje się postawa antropologiczna, w której osoba nauczająca słucha, obserwuje, jest świadoma nieporozumień czy konfliktów (C. Paulston za B. McLeod 1976: 212-213). Oczywiście z dzisiejszej i bogatszej perspektywy możemy dodać, że należy mieć na uwadze to, że uczący się mogą nie pasować do uogólnionych wniosków i wypracowanych na ich podstawie podejść, przejawiać inne od założonych postawy, oczekiwania, potrzeby itd.

B. McLeod sugeruje zachęcanie uczących się do rozwijania swojej postawy antropologicznej. Dzięki niej mają szansę stać się bardziej aktywni i zaangażowani w proces uczenia się ${ }^{26}$. Uczący staje się amatorem antropologiem/ amatorką antropolożką a także źródłem wiedzy dla nauczających - i to w ramach zajęć stwarzających okazję do stawiania pytań na drażliwe tematy oraz stawiania hipotezy odnośnie kultury, zadawania pytań, radzenia się u nauczających - bez lęku o ocenę czy urażenie/ obrażenie kogoś. Wydaje się to niezbędne, ponieważ obserwuje się, że zachowania osób dorosłych są niechętnie korygowane a przez to istnieje ryzyko ich popełniania. Nauczający powinni zadawać pytania, by zwiększać swoją wiedzę, zgodnie z założeniem, że nauczający i uczący stają się dla siebie jej źródłem. Dzięki takiej postawie część z potencjalnych problemów może zostać zminimalizowana lub uniknięta np. lęk przed zagrożeniem własnej identyfikacji i kultury czy współzawodnictwo w grupie. ${ }^{27}$ Uczący się, mówiąc o własnej kulturze, staje się ekspertem/ ekspertką - wzmacnia zaufanie do samego/ samej siebie. Celem ponadto staje się umiejętność komunikacji społecznej; możliwość wyrażania swoich wartości, wzorów zachowania, rozwoju wiedzy i umiejętności w stosunku do nabywanych języka i kultury oraz kultury rodzimej (wyjściowej) (B. McLeod 1976: 213-217). Od nauczających zależy wytworzenie dobrej atmosfery, w której współzawodnictwo i ewentualne wątpliwości, lęki mogą być przekute w wzbogacające doświadczenie. To wykorzystywanie potencjału różno- i wielokulturowego uczestników i uczestniczek zajęć może być okazją do wzbogacenia ich postawy międzykulturowej.

Wydaje się, że postawa antropologiczna nauczających może stawać się dobrym modelem postaw proaktywnych i źródłem inspirujących refleksji. Szacunek oraz dowartościowanie obydwu stron interakcji - nauczania/ uczenia się języka - stanowią o zorientowanej humanistycznie, a przez to refleksyjnie postawie, której efektywność zdaje się być celem nadrzędnym.

\footnotetext{
${ }^{26}$ Dziś w tym kontekście przychodzi nam na myśl autonomia uczących się, nauczających - fakultatywnie półautonomia i autonomizacja (zob. W. Wilczyńska 1999).

${ }^{27}$ Uwagi poczynione na gruncie amerykańskim mogą być aktualne także w polskim kontekście. Jest to związane z rosnącą różnorodnością społeczeństwa polskiego oraz potrzebą integracji uchodźców i uchodźczyń.
} 


\section{Podsumowanie}

Dzięki badaniom jakościowym a także podejściu refleksyjnemu można dostrzec m.in. (między)kulturowe aspekty nauki języków obcych. Z perspektywy antropologicznej obserwujemy wpływ decyzji, opinii, stereotypów, wyborów, nieuświadomionych postaw etc. na nauczanie/ uczenie się. Poprzez nie zdobywamy możliwość uwzględnienia tych doświadczeń w wyrabianiu i zwiększaniu/ umacnianiu postawy refleksyjnej nauczających oraz uczących się - traktujących się partnersko w procesie uczenia (się), co ostatecznie skutkuje efektywniejszymi procesami nauczania. Wydaje się, że postawa refleksyjna umożliwia dostęp do kulturowego wymiaru zjawisk, ponadto pozwalając na lepsze przystosowanie metod nauczania, ale także i badawczych do języków innych niż np. wszechstronnie opisywany angielski.

Uważam, że współczesna wielokulturowość oraz wielojęzyczność sprawiają, że niemożliwe jest wypracowanie uniwersalnych metodycznych czy dydaktycznych narzędzi/ zasad (nawet w obrębie jednego języka czy jednej „kultury narodowej”), które mogłyby odpowiadać na potrzeby przede wszystkim uczących się, w tym za prawidłową komunikację - czy w ramach grup homogenicznych, heterogenicznych, zajęć indywidualnych czy grupowych. Dynamika procesów grupowych, a także indywidualne cechy osobowościowe podważają możliwość wypracowania takich rozwiązań. Jednak, odwołując się do np. dokonań antropologii kulturowej, etnografii i ich zastosowań w glottodydaktyce (M. Byram, P.E. Gębal, A. Jaroszewska, B. McLeod, A. Michońska-Stadnik, W. Wilczyńska, G. Zarzycka), można tworzyć środowisko, w którym różnice kulturowe staną się źródłem twórczej pracy, rozwoju zarówno kompetencji językowych jak i międzykulturowych uczących oraz nauczających.

Role uczących się oraz nauczających są dynamiczne i wymienne. Współtworzą oni sytuację, w której uczący się rozwija swoje umiejętności językowe, a osoba nauczająca może rozwinąć również swoje kompetencje nauczycielskie, międzykulturowe a także językowe - o ile potraktuje uczącego się jako eksperta/ ekspertkę np. od jego/ jej języka wyjściowego/ kultury wyjściowej, a zwłaszcza od jego/ jej specyfiki - indywidualnej i kulturowej. Koresponduje to z obserwacją, w której we współczesnych trendach, metodach odchodzi się od monologiczności nauczających i przechodzi ku podmiotowemu oraz autonomizującemu traktowaniu uczących się.

Warto uwzględniać teorie osobiste nauczających oraz uczących się i to, jakie są ich cele, potrzeby, oczekiwania a także wyobrażenia wynikające również ze wcześniejszych doświadczeń. Celem jest oddanie głosu innym, żeby zobaczyć, kim są i czego potrzebują. Dzięki temu może to stać się częścią ich doświadczania szeroko rozumianej polskości, zdobywania kompetencji międzykulturowych, stając się przez to pożądanym narzędziem w ich ale i naszych doświadczeniach.

Reasumując, perspektywa międzykulturowa - refleksyjna i antropologizująca jest angażująca i zakłada zmianę (w) uczących się i nauczających. Cel ten można osiągnąć poprzez odnoszenie się do doświadczeń uczących się i nauczających, języków i kultur już znanych. W ten sposób uczący się wychodzą ponad własną dotychczasową znaną im językową oraz (między)kulturową perspektywę, poprzez którą rozumieją swój świat i konstytuują go. Kluczową rolę w tych procesach poznania odgrywa empatia i zasady dobrego komunikowania się oraz otwarcie (się) na Innego i/ lub Obcego. 


\section{Bibliografia}

Andersen, H. L./ K. Lund/ K. Risager (2006), Culture in Language Teaching, (w:) H.L. Andersen, K. Lund, K. Risager (red.), Culture in Language Learning. Aarhus, $11-27$.

Atkinson, P./ M. Hammersley (2000), Metody badań terenowych, Poznań.

Byram, M. (2010), Linguistic and Cultural Education for Bildung and Citizenship, (w:) The Modern Language Journal (94), 317-321.

Coste D./ B. North/ J. Sheils/ J. Trim (2003), Europejski system opisu kształcenia językowego: uczenie sie, nauczanie, ocenianie, Warszawa.

Dąbrowska, A./ U. Dobesz/ M. Pasieka (2010), Co warto wiedzieć: poradnik metodyczny dla nauczycieli języka polskiego jako obcego na Wschodzie, Warszawa.

Flick, U. (2011a), O serii Niezbędnik badacza, (w:) B. Gibbs (red.), Analizowanie danych jakościowych. Warszawa, 11-17.

Flick, U. (2011b), O tej książce [wstęp], (w:) B. Gibbs (red.), Analizowanie danych jakościowych. Warszawa, 17-18.

Garncarek, P. (2006) Przestrzeń kulturowa w nauczaniu języka polskiego jako obcego, Warszawa.

Gębal, P.E (2009), Realioznawstwo w nauczaniu języka niemieckiego, (w:) W.T. Miodunka (red.), Kultura w nauczaniu języka polskiego jako obcego, stan obecny programy nauczania - pomoce dydaktyczne. Kraków, 69-94.

Gębal, P.E (2010), Dydaktyka kultury polskiej w ksztatceniu językowym cudzoziemców, Podejście porównawcze, Kraków.

Gębal, P.E (2013), Modele kształcenia nauczycieli języków obcych w Polsce i Niemczech, W stronę dydaktyki porównawczej, Kraków.

Gębal, P.E (2014), Krakowska szkoła glottodydaktyki porównawczej na tle rozwoju glottodydaktyki ogólnej i polonistycznej, Kraków.

Gibbs, G. (2011), Analizowanie danych jakościowych, Warszawa.

Heidari, A./ S. Ketabi/ R. Zonoobi (2014), The Role of Culture Through the Eyes of Different Approaches to and Methods of Foreign Language Teaching, (w:) Journal of Intercultural Communication (34) 6, [dostęp 09.07.2014].

Jaroszewska, A. (2013), Nauczanie języków obcych seniorów w Polsce, Analiza potrzeb i możliwości w aspekcie międzykulturowym. Kraków.

Kirkebæk, M. J./ Du X(iang-Yun,)/ A.A. Jensen (2013), The Power of Context in Teaching and Learning Culture, (w:) J. M. Kirkebæk/ X.-Y. Du/ A.A. Jensen (red.), Teaching and Learning Culture, Negotiating the Context. Rotterdam-Boston-Taipei, 1-12.

Kramsch, C. (2006), Culture in Language Teaching, (w:) H.L. Andersen/ K. Lund/ K. Risager (red.), Culture in Language Learning. Aarhus, 11- 27.

McLeod, B. (1976), The Relevance of Anthropology to Language Teaching, (w:) TESOL Quarterly 2, 211-220.

Michońska-Stadnik, A. / W. Wilczyńska W. (2010), Metodologia badań w glottodydaktyce, Kraków.

Miodunka, W.T. (2009a), Czy kultura była traktowana po macoszemu w nauczaniu języka polskiego jako obcego? Rozważania na marginesie ksiażki Anny Burzyńskiej, w: Kultura w nauczaniu jezzyka polskiego jako obcego, stan obecny - programy nauczania - pomoce dydaktyczne, (w:) W.T. Miodunka (red.), Kultura w nauczaniu języka polskiego jako obcego, stan obecny - programy nauczania - pomoce dydaktyczne. Kraków, 13-35. 
Miodunka, W.T. (2009b), Kompetencja socjokulturowa w nauczaniu języka polskiego jako obcego/Zarys programu nauczania, (w:) Kultura w nauczaniu języka polskiego jako obcego stan obecny - programy nauczania - pomoce dydaktyczne, w:) W.T. Miodunka (red.), Kultura w nauczaniu języka polskiego jako obcego, stan obecny - programy nauczania - pomoce dydaktyczne. Kraków, 97-117.

Piekot, T./ G. Zarzeczny (2010), Między zdrowym rozsadkiem a polityczna poprawnościa - polskie podręczniki do nauczania języka polskiego jako obcego oczami cudzoziemców, (w:) Acta Universitatis Lodziensis. Kształcenie Polonistyczne Cudzoziemców 17, 517-528.

Piotrowska-Skrzypek, M. (2008), Uczę (się) refleksyjnie, więc jestem... autonomiczny? - podejście refleksyjne na lekcjach języka obcego w gimnazjum, (w:) M. Pawlak (red.), Autonomia w nauce języka obcego - co osiągnęliśmy i dokąd zmierzamy. Poznań/ Kalisz/ Konin. 245-255.

Ruiz de Zarobe, L./ Y. Ruiz de Zarobe (2012), Introduction: Pragmatics across Languages and Cultures, (w:), L. Ruiz de Zarobe/ Y. Ruiz de Zarobe (red.), Speech Acts and Politeness across Languages and Cultures. Bern, 9-23.

Torenc M. (2007) Nauczanie międzykulturowe - implikacje glottodydaktyczne, Wrocław.

Wilczyńska, W. (1999), Uczyć się czy być nauczanym?, O autonomii w przyswajaniu języka obcego. Warszawa/ Poznań.

Wilczyńska, W. (2007), Wielojęzyczność - przegląd problematyki w ujęciu dydaktycznym, (w:) M. Jodłowiec/ A. Niżegorodcew (red.), Dydaktyka języków obcych na początku XXI wieku. Kraków, 27-40.

Zarzycka, G. (2000a), Dialog międzykulturowy, Teoria i opis komunikowania się cudzoziemców przyswajajacych język polski. Łódź.

Zarzycka, G. (2000b), Etnocentryzm, polonocentryzm, wielokulturowość, wielogłosowość... - opis orientacji obecnych w nauczaniu języków obcych, (w:) J. Mazur (red.), Polonistyka w świecie. Nauczanie języka i kultury polskiej studentów zaawansowanych. Lublin, 61-89. 